JURNAL UPI

\title{
DUGAAN PENYELEWENGAN PROGRAM EKONOMI BENTENG UNTUK KEPENTINGAN PEMILIHAN UMUM 1955
}

\author{
Moch. Dimas Galuh Mahardika, Fahmi Nur Ramadhan \\ Prodi. Pendidikan Sejarah, Universitas Negeri Sebelas Maret \\ dimasgaluhmahardika@gmail.com
}

\begin{abstract}
To cite this article: Mahardika, M.D.G., \& Ramadhan, F,N. (2021). Dugaan penyelewengan program ekonomi benteng untuk kepentingan pemilihan umum 1955. HISTORIA: Jurnal Pendidik dan Peneliti Sejarah, 4(2), 123-130. https://doi. org/10.17509/historia.v4i2.28697.
\end{abstract}

Naskah diterima : 4 Oktober 2020, Naskah direvisi : 18 Mei 2021, Naskah disetujui : 7 Juni 2021

\begin{abstract}
After the proclamation of independence of the Republic of Indonesia on August 17, 1945, the government began to improve the development of the country. The government's top priority was to improve people's living standards, one of which was by improving the economic sector. Various efforts were made by the government, with one of them implementing the Benteng Economy Program. The monetary policy was prioritized for indigenous traders to create quality indigenous entrepreneurs. The purpose is contrary to the implementation practice, and the Benteng economic program is instead used as one of the mediums to reap profits. This is strengthened by several strategic positions in the governance structure filled by the majority of PNI members. Some strategic positions in the cabinet and government held by the PNI, namely the Minister of Foreign Affairs (Mr. Sunario), Minister of Finance (Dr. Ong Eng Die), Minister of Economy (Mr. Iskaq Tjokrohadisoerjo). In addition, another good thing is that on November 4, 1953, the cabinet formed the Indonesian Election Committee (PPI) chaired by S. Hadikusumo, a PNI cadre. This article was written using historical methods to explain the alleged misappropriation of the Benteng Economic Program for the benefit of the Partai Nasional Indonesia in the 1955 General Election.
\end{abstract}

Keywords: Benteng Economics Program; Indonesian Election Committee; Indonesian National Party; the 1955 General Election;

\begin{abstract}
Abstrak
Setelah diproklamirkannya kemerdekaan Republik Indonesia pada tanggal 17 Agustus 1945, pemerintah mulai berbenah membangun negeri. Prioritas utama pemerintah saat itu adalah meningkatkan taraf hidup masyarakat, salah satunya dengan memperbaiki sektor ekonomi. Berbagai usaha dilakukan oleh pemerintah dengan salah satunya menerapkan Program Ekonomi Benteng. Kebijakan ekonomi benteng diprioritaskan untuk pedagang pribumi, dengan tujuan menciptakan kalangan pengusaha pribumi yang berkualitas. Tujuan tersebut bertolak belakang di dalam praktik pelaksanaannya, program ekonomi benteng justru dijadikan salah satu medium untuk meraup keuntungan. Hal ini dikuatkan dengan beberapa posisi strategis dalam struktur pemerintahan yang diisi oleh mayoritas anggota PNI. Beberapa kedudukan yang strategis dalam kabinet dan pemerintahan yang dipegang oleh PNI, yaitu Menteri Luar Negeri (Mr. Sunario), Menteri Keuangan (Dr. Ong Eng Die), Menteri Perekonomian (Mr. Iskaq Tjokrohadisoerjo). Selain itu, hal lain yang menguntungkan adalah bahwa pada tanggal 4 November 1953, kabinet membentuk Panitia Pemilihan Indonesia (PPI) yang diketuai oleh S. Hadikusumo yang juga seorang kader PNI. Artikel ini ditulis dengan menggunakan metode historis untuk memberikan penjelasan terkait dengan dugaan penyelewengan Program Ekonomi Benteng untuk kepentingan Partai Nasional dalalm Pemilihan Umum 1955.
\end{abstract}

Kata Kunci: Panitia Pemilihan Indonesia; Partai Nasional Indonesia; Pemilihan Umum 1955; Program Ekonomi Benteng.

HISTORIA: Jurnal Pendidik dan Peneliti Sejarah, p-issn:2620-4789 | e-issn:2615-7993 


\section{PENDAHULUAN}

Perjalanan politik pemerintahan Indonesia pasca kemerdekaan diwarnai oleh berbagai dinamika. Kemerdekaan yang diproklamirkan pada 17 Agustus 1945 masih bersifat secara de-facto, artinya secara hukum (dejure) Belanda sebagai negara yang sebelumnya berkuasa di wilayah Indonesia masih belum bersedia untuk mengakui kemerdekaan Indonesia. Setelah pemerintah Indonesia merdeka melalui berbagai proses diplomasi yang panjang, Belanda baru mengakui kemerdekaan Indonesia secara de-jure pada 1949 pada Konferensi Meja Bundar yang diselenggarakan di Den Haag. Masuk di tahun 1950, babakan perjalanan sejarah Indonesia baru dimulai, yang secara konstitusional masih bertahan dengan demokrasi parlementer (Drakeley, 2005). Beberapa partai besar yang eksis dalam kancah politik Indonesia pada saat itu di antaranya Masyumi, PNI, NU, dan PKI. Salah satu pekerjaan besar yang menjadi fokus perhatian adalah sektor ekonomi.

PNI sebagai partai incumbent terlihat sangat getol di dalam menyuarakan persoalan ekonomi. Pada bulan Maret 1950, 24 anggota parlemen PNI mengadakan konferensi di Jakarta untuk membahas persoalan tersebut. Dalam konferensi itu, Ketua Umum Sujono Hadinoto menegaskan bahwa fraksi akan terus bertindak sesuai dengan Piagam dan Prinsip Partai untuk menciptakan ekosistem perekonomian yang berbasis kerakyatan dengan prinsip gotong royong. Nada serupa juga terdengar dari Ruslan Abdul Gani sebagai salah satu pentolan PNI yang menegaskan bahwa partainya merasa tidak terima apabila Belanda masih memegang kendali atas kepentingan ekonomi Indonesia (Pham, 2019).

Sebagai negara yang merdeka, Indonesia bertekad untuk meningkatkan taraf hidup rakyatnya dengan merombak struktur ekonomi kolonial yang telah membelenggu Indonesia selama masapenjajahan menjadi ekonomi nasional yang mencerminkan kemerdekaan Indonesia. Struktur perekonomian kolonial yang berkembang di Indonesia sebagai warisan dari penjajah Belanda bergantung pada kegiatan produksi pertanian dan perkebunan, sedangkan kegiatan modern seperti pertambangan, distribusi transportasi dan perbankan dikuasai oleh perusahaan-perusahaan asing.

Ketika Republik Indonesia mendapatkan pengakuan kedaulatan atas kekuasaannya di wilayah bekas Hindia Belanda pada 27 Desember 1949 dalam KMB (Konferensi Meja Bundar), negara ini sebelumnya menghadapi berbagai permasalahan yang serius. Walaupun pengakuan kedaulatan Republik Indonesia disambut dengan gembira oleh rakyat, namun banyak kaum nasionalis yang merasa tidak senang dengan beratnya persyaratan yang dibebankan Belanda kepada Indonesia sebagai imbalan atas pengakuan kedaulatan tersebut. Salah satu syarat tersebut yaitu Indonesia harus memberi izin beroperasi kembali perusahaanperusahaan Belanda di Indonesia, selain itu Indonesia juga harus mengambil alih hutang Pemerintah Hindia Belanda di Indonesia. Seluruh hutang tersebut mencapai USD 1,13 miliar dalam negeri dan hutang luar negeri. Dampak dari pengambil alihan hutang tersebut membuat perekonomian Indonesia menjadi semakin terancam (Thee, 2005).

Syarat yang sangat merugikan itu masih ditambah dengan dominasi perusahaan Belanda yang bergerak di sektor ekonomi modern dengan berskala besar yang menyumbang sekitar 25\% dari PDB (Dick dkk., 2002). Alhasil ruang gerak untuk aktifitas ekonomi kaum pribumi masih sangat kecil. Hal itu yang kemudian mendorong pemerintah Republik Indonesia untuk segera melaksanakan pembangunan nasional yang lebih terencana dan intensif. Pembangunan nasional Indonesia di bidang ekonomi yang diprioritaskan untuk mengubah struktur ekonomi kolonial menjadi ekonomi nasional berbasis pemberdayaan aktifitas ekonomi untuk kalangan pribumi adalah Program Benteng (Lindblad, 2019; Lindblad, 2010).

Tabel 4.1 Dominasi Perusahaan Belanda dalam Perdagangan Indonesia 1950-1957 (dalam presentase)

\begin{tabular}{lllll}
\hline Tahun & $\begin{array}{l}\text { Pangsa } \\
\text { Indonesia } \\
\text { dalam impor } \\
\text { Belanda }\end{array}$ & $\begin{array}{l}\text { Pangsa } \\
\text { Indonesia } \\
\text { dalam ekspor } \\
\text { Indonesia }\end{array}$ & $\begin{array}{l}\text { Pangsa } \\
\text { Belanda } \\
\text { dalam } \\
\text { impor } \\
\text { Indonesia }\end{array}$ & $\begin{array}{l}\text { Pangsa } \\
\text { Belanda } \\
\text { dalam } \\
\text { ekspor } \\
\text { Indonesia }\end{array}$ \\
\hline 1950 & - & - & 17.2 & 25.3 \\
\hline 1951 & - & - & 12 & 20.6 \\
\hline 1952 & 6.4 & 5.6 & 13 & 21.4 \\
\hline 1953 & 5.5 & 3.6 & 11.8 & 23 \\
\hline 1954 & 4.8 & 2.6 & 10.5 & 19.5 \\
\hline 1955 & 3.0 & 2.5 & 11.7 & 15.8 \\
\hline 1956 & 3.1 & 2.9 & 10.7 & 19.5 \\
\hline 1957 & 2.9 & 2.3 & 9.8 & - \\
\hline
\end{tabular}

Sumber: Het Economisch Belang van Indonesië voor Nederland dalam Pham, 2019.

Program Benteng yang dilaksanakan pada tahun 1950 - 1957 lebih mengutamakan sektor perdagangan karena pemerintah beranggapan bahwa dengan membangun sektor perdagangan, taraf perekonomian Indonesia dapat meningkat. Hal ini di latar belakangi oleh besarnya pendapatan Indonesia melalui perdagangan. Kurang lebih $80 \%$ dari hasil pendapatan negara seluruhnya berupa bea impor dan ekspor, bea

HISTORIA: Jurnal Pendidik dan Peneliti Sejarah, p-issn:2620-4789 | e-issn:2615-7993 
cukai (accijnzenen heffingen) serta pajak-pajak perseroan terdiri dari pendapatan dilapangan perdagangan (Dick dkk., 2002). RUP (Rancangan Urgensi Perekonomian) sebagai kebijakan yang bertujuan untuk menumbuhkan pengusaha pribumi. RUP ini lebih dikenal dengan sebutan Program Benteng dan bertujuan untuk memperkuat masyarakat pribumi Indonesia agar mampu menjadi pengusaha yang tangguh dan bersaing dengan pengusaha etnis Tionghoa dan Belanda yang lebih dulu terbentuk di Indonesia (Febrari, 2015).

Pengusaha pribumi Indonesia yang ingin mendapatkan lisensi impor maka harus mendaftar ke Kantor Lembaga Alat-alat Pembayaran Luar Negeri (LAAPLN) di Jalan Gajah Mada (Setiono, 2008). Para pengusaha pribumi Indonesia yang mendapatkan bantuan dan perlindungan dari Program Benteng ini dikenal dengan sebutan importir-importir benteng, sedangkan barang-barang yang diimpor oleh mereka disebut dengan barang-barang benteng. Para importir pribumi Indonesia harus melakukan usaha untuk menjamin kelancaran pengiriman barang yang datang dari luar negeri sehingga rakyat dapat membeli kebutuhan dengan harga yang murah dan harganya efisien (Komala, 2012).

Terdapat beberapa syarat yang harus dipenuhi bagi para pengusaha pribumi untuk bisa mendapatkan lisensi impor dari program benteng ini (Komala, 2012) yaitu:

1. Mereka harus merupakan importir baru.

2. Mempunyai status yang sah sebagai badan hukum atau perseroan terbatas atau suatu kongsi.

3. Memiliki modal kerja minimal Rp. 100.000.

4. Memiliki ruangan kantor yang cukup luas untuk beberapa orang pegawai tetap.

5. Memiliki pegawai yang telah perpengalaman dalam perdagangan atau kegiatan usaha lainnya.

6. Sekurang-kurangnya $70 \%$ dari kerja yang dimiliki harus berasal dari golongan pribumi (bangsa Indonesia sendiri) sementara orang-orang asing atau orang-orang Indonesia keturunan asing lainnya diperbolehkan memiliki sebanyak-banyaknya 30\% dari modal kerja perusahaan.

Program Benteng masih terus berlanjut walaupun pemerintahan Republik Indonesia Serikat (RIS) berakhir. Mulai dari Kabinet Natsir (September 1950 - April 1951) sampai dengan Kabinet Ali Sastroamidjojo I (Agustus 1953 - Juli 1955). Pada masa pemerintahannya Kabinet Ali masih tetap menjalankan Program Benteng. Akan tetapi pada kondisi perekonomian Indonesia semakin lesuh. Hal ini terjadi akibat tekanan inflasi, perdagangan luar negeri yang kacau balau, pembatasan impor dan masih banyak lagi. Menurut Oey (1991) pemerintah Kabinet Ali melakukan beberapa kegiatan yang ditujukan untuk menanggulangi segala permasalahan yang ada, di antaranya adalah sebagai berikut:

1. Pemerintah mengadakan pembatasan yang kuantitatif yang drastis terhadap impor berupa penyediaan hanya Rp. 50 seminggu untuk seluruh impor dan bukan pemerintah.

2. Penyetoran di mana yang harus oleh importir dinaikkan dengan presentase yang cukup besar.

3. Dikenakan pungutan terhadap pembayaran jasa keluar negeri yang dinamakan tambahan pembayaran transfer TPT sebesar $66 \quad 2 / 3 \%$ atas jumlah yang diizinkan untuk dikirim.

Pemerintahan ini menjadi semakin buruk lagi ketika Menteri Perekonomian masa itu yaitu Iskaq Tjokrohadisoerjo mengubah struktur pembagian devisa serta mengeluarkan surat edaran P.41 yang berisi importir pribumi disediakan lisensi devisa sebesar $80 \%$ sampai $90 \%$. Surat tersebut mengandung pro dan kontra dan akhirnya surat tersebut dicabut karena Menteri Iskaq Tjokrohadisoerjo membuat surat tersebut tanpa musyawarah dan persetujuan dari Dewan Moneter (Komala, 2012).

Pada tahun 1955, Indonesia mencoba menerapkan sistem demokrasi dengan melaksanakan pemilu pertama. Demokrasi adalah pemerintahan dari rakyat, oleh rakyat, dan untuk rakyat, pada posisi ini rakyat berperan langsung dalam pemerintahan dan kekuasaan tertinggi dipegang oleh rakyat (Kantaprawira, 2004). Sarana dari demokrasi adalah pemilihan umum yang ditujukan untuk menampung aspirasi rakyat dalam pemerintahan. Pemilihan umum adalah mekanisme politik yang memiliki hubungan erat dalam sistem politik demokrasi dengan harapan aspirasi masyarakat yang beragam akan dapat tersalurkan melalui partaipartai politik atau calon-calon yang mereka dukung (Maarif, 1996).

Pemilihan umum pada tahun 1955 merupakan pemilihan umum pertama yang diselenggarakan di Indonesia dengan dua tahap yaitu pada tanggal 29 September 1955 untuk memilih anggota DPR dan pada tanggal 15 Desember 1955 untuk memilih anggota Dewan Konstituante (Poesponegoro \& Notosusanto, 2010). Berdasarkan pasal 35 UUDS 1950 dan juga pasal 135 ayat 2 menentukan bahwa asas pemilihan umum 1955 adalah langsung, umum, bebas, rahasia dan berkesamaan. Pemilu 1955 berlangsung dengan sistem proporsional (multimember contituency) dan dikombinasikan dengan sistem daftar (list system) yang diikuti oleh lebih dari 30 partai politik dan lebih dari 100 organisasi atau perseorangan (Widagdo, 1995).

Dalam pemilihan umum anggota DPR diikuti peserta sebanyak 118 peserta pemilu yang terdiri 
atas 36 partai politik, 34 organisasi, 48 perorangan. Sementara itu, peserta pemilihan umum anggota Konstituante sebanyak 91 peserta yang terdiri dari 39 partai politik, 23 organisasi, dan 29 perorangan. Feith (1999) mengelompokan peserta pemilihan umum 1955 berdasarkan perolehan kursinya menjadi partai besar (PNI, Masyumi, Nahdatul Ulama, PKI), partai menengah (PSII, Parkindo, Partai Katholik, PSI, Perti, IPKI), kelompok kecil yang bercakupan Nasional, dan kelompok kecil yang bercakupan daerah. Dari 172 kontestan Pemilu 1955, hanya 28 kontestan (tiga diantaranya perseorangan) yang berhasil memperoleh kursi.

Artikel ini mencoba untuk menjelaskan program ekonomi Benteng dan pelaksanaannya yang dinilai kurang tepat sasaran dari tujuan awal. Praktik korupsi dan nepotisme marak terjadi ketika munculnya fenomena "Ali-Baba". Pejabat negara yang memegang kekuasaan pada saat itu terindikasi kurang bijaksana di dalam menjalankan program ekonomi Benteng ini, dan memiliki kecenderungan untuk menguntungkan pihak tertentu yang kaitannya nanti dengan penyuksesan partai dalam pemilu tahun 1955.

\section{METODE}

Artikel ini ditulis dengan menggunakan metode historiografi yang dilaksanakan dalam empat tahap (Kuntowijoyo, 2005):

1. Penentuan Topik. Penulis memilih topik dalam kurun waktu tahun 1950an dengan spesifik pembahasan terkait dengan Program Ekonomi Benteng dan penyelewengan yang terjadi di dalamnya, serta kaitannya dengan pemilu 1955.

2. Pengumpulan Sumber.Sumber yang digunakan dalam artikel ini adalah sumber sekunder berupa buku, dan jurnal ilmiah sesuai pembahasan yang relevan dengan judul yang diusung dalam artikel ini.

3. VerifikasiSumber.Sumberyangterkumpulkemudian ditelaah untuk menentukan keabsahan informasi yang tertuang di dalamnya. Sumber berupa jurnal ilmiah dan buku dapat dipertanggungjawabkan secara akademis.

4. Interpretasi. Penulis melakukan telaah dari berbagai sumber yang telah didapatkan untuk menemukan fakta dan merangkainya dalam bentuk narasi

5. Historiografi. Hasil telaah dan penafsiran kemudian dituliskan dalam bentuk narasi sesuai dengan sistematika dan tata cara penulisan artikel yang telah ditentukan.
Serangkaian proses dalam penulisan artikel ini menggunakan metode prosedural yang telah disepakati sebagai metode penelitian sejarah/metode historis untuk mengetahui kejadian di masa lalu secara akademis (Gottschalk, 1969; Schaff, 1976) khususnya pembahasan terkait dengan "Dugaan Penyelewengan Program Ekonomi Benteng Untuk Kepentingan Partai Nasional Indonesia dalam Pemilihan Umum 1955.

\section{PEMBAHASAN}

\section{Penyelewengan Program Benteng}

Program Benteng yang ditujukan untuk menumbuhkan dan membentuk pengusaha pribumi serta menyaingi perusahaan-perusahaan Belanda yang tergabung dalam "The Big Five" berjalan kurang berhasil. Ketidakberhasilan tersebut dikarenakan dalam praktiknya program ini menimbulkan cukup banyak penyelewengan, karena importir etnis Tionghoa yang dikecualikan dalam program ini dapat memperoleh lisensi impor. Mereka dapat beroperasi lewat pemegang lisensi pengusaha pribumi Indonesia baik dengan membeli atau menyewa lisensi tersebut. Pengusaha pribumi ini biasanya disebut juga "importir aktentas" (Krekhof, 2005). Importir aktentas merupakan pengusaha yang tidak bermodal dan tidak mempunyai kantor. Mereka hanya membawa aktentas keluar masuk kantor-kantor instansi pemerintah, terutama kantor Lembaga Alat-alat Pembayaran Luar Negeri (LAAPLN) di Jalan Gajah Mada untuk mendapatkan lisensi impor (Setiono, 2008).

Kerjasama di antara pengusaha pribumi Indonesia dan pengusaha etnis Tionghoa ini memunculkan fenomena baru yang disebut dengan istilah "AliBaba". Perusahaan ini secara resmi dimiliki oleh "Ali" seorang pengusaha pribumi yang keluar masuk kantor pemerintah mencari lisensi dan fasilitas sementara "Baba" seorang pengusaha etnis Tionghoa yang menjalankannya (Setiono, 2008). Program Benteng bukannya menumbuhkan dan membentuk pengusaha pribumi Indonesia yang kuat, melainkan malah mendorong terbentuknya kelompok pemburu rente yang tidak produktif secara sosial. Kelompok pemburu rente tersebut "Menjadi kaya raya tanpa bekerja" berbekal tameng atas nama pribumi, mereka menjual lisensi sebagai importir (Tim Buku Tempo, 2010). Mereka menikmati rente ekonomi yang luar biasa empuknya hanya karena mempunyai akses dan lobi kepada Menteri Perekonomian. Secara tajam, Thee (2005) mengatakan bahwa program benteng ini adalah bencana bagi pengusaha pribumi Indonesia. Hanya segelintir orang Indonesia saja yang dapat menikmati hasil dari program ini. Para pedagang atau pengusaha asing tetap memiliki 
ruang untuk melakukan aktifitas ekonomi (Matansi, 2017).

Dugaan penyelewengan yang terjadi pada Program Benteng itu utamanya dilakukan pada masa Kabinet Ali I dengan memberikan lisensi-lisensi impor berdasarkan pertimbangan-pertimbangan partai politik. Menteri Perekonomian Iskaq Tjokrohadisoerjo telah memberi lisensi yang tidak adil karena sebagian penerima lisensi tersebut merupakan anggota-anggota Partai Nasional Indonesia (PNI) (Glassburner, 1962). Subjektifitas yang dilakukan oleh Iskaq Tjokrohadisoerjo dalam memberikan memberikan lisensi rupanya terjadi karena ia belum menyusun rencana yang detail dan rinci secara mendasar tentang operasional pembangunan sektor perekonomian yang akan ia laksanakan, sehingga dalam mengambil segala keputusan khususnya terkait pemberian izin lisensi impor menuai berbagai kontroversi (Yani, 1995).

Dalam Konferensi Ekonomi Seluruh Sumatera, November 1954, Hatta sempat memberikan kritikan sebagai ungkapan kekecewaan pada kebijakan ekonomi yang diberlakukan oleh pemerintah. Kebijakan itu lebih mementingkan kepentingan pribadi dan juga kepentingan golongan daripada kepentingan rakyat banyak. "Berpuluh juta... ya, barangkali beratus juta rupiah uang negara, yang diperoleh dari pajak rakyat, sudah dikorbankan untuk kepentingan satu golongan kecil atas nama nasional" (Tim Buku Tempo, 2010).

Sejak 1950 badan atau kantor yang ditugaskan menyelenggarakan kegiatan impor benteng adalah KPUI yang berada di bawah pimpinan Jawatan Perdagangan dan Kementerian Perekonomian (Sukainah, 2016). Bagian dari pejabat pemerintahan yang melakukan penyelewengan kekuasaan dan jabatan dengan tindak korupsi ialah Kantor Pusat Urusan Impor (KPUI). Penyelewengan itu biasanya dilakukan untuk mempercepat proses urusan surat menyurat bagi para pengusaha pribumi untuk urusan pelaksanaan impor barang-barang Benteng. Tindakan peyelewengan yang menyalahi aturan itu menyebabkan banyak importir yang tidak dapat memperoleh hak lisensi devisa dikarenakan tidak sanggup membayar uang "pelicin", sedangkan hal yang sebaliknya terjadi pada importir yang mempunyai uang pelicin dengan mudah mendapatkan lisensi devisa walaupun tidak memenuhi syarat administratif pada KPUI (Komala, 2012).

Pada bulan Maret 1951 kabinet Sukiman menggunakan sertifikat devisa untuk memantau aktifitas impor. Sejumlah besar izin impor dicadangkan untuk importir asli Indonesia. Pada tahun 1952, 43\% dari semua devisa dialokasikan kepada importir asli Indonesia, yang memberikan mereka keuntungan cukup besar dibandingkan perusahaan-perusahaan Eropa (31\%) dan pedagang Cina (26\%). Kuantitas pengimpor Benteng meningkat dari 250 pada akhir 1950 menjadi 741 pada bulan April 1952 (Pham, 2019). Namun eksistensi pengusaha pribumi digoyahkan oleh oposisi pengusaha Cina, ditambah lagi kemampuan SDM pribumi kebanyakan yang pada saat itu belum memahami secara mendalam tentang ilmu perekonomian dan inflasi yang terjadi secara terus-menerus membuat pemerintah harus mengevaluasi kembali pelaksanaan program tersebut (Wijayanti, 2015).

Dugaan penyelewengan yang terjadi baik dari pejabat pemerintah atau dari para pengusaha pribumi mengakibatkan kebijakan Program Benteng mengalami kegagalan. Kegagalan yang terjadi menandakan bahwa benteng ekonomi yang dibangun oleh Pemerintah Indonesia sangat terhadap gunjangan dari sisi dalam. Gunjangan paling terasa terjadi terhadap praktik nepostisme dan korupsi dikalangan pejabat pemerintah serta ketidak kompetennya para pengusaha pribumi pemilik pemilik lisensi impor. Kekacauan politis yang timbul dalam pelaksanaan program ekonomi benteng menyebabkan kestabilan ekonomi melenceng dari tujuan awal-membangun ekosistem perekonomian untuk pribumi (Boediono, 2005).

\section{Manuver Politik PNI dalam Pemilihan Umum 1955}

Pada tanggal 4 April 1953, pemerintah mengesahkan Undang-Undang yang mengatur tentang pelaksanaan pemilu (Ibrahim, 1981). Dengan demikian, partai-partai menganggap hal tersebut sebagai dimulainya masa pengenalan atau kampanye terhadap calon pemilih. Berbagai program ditawarkan agar mendapatkan suara terbesar dan memenangkan pemilu. Tiap-tiap partai mewacanakan berbagai pesan pada para calon pemilih. Kemudian pada tanggal 31 Mei 1954, pemerintah melalui Panitia Pemilihan Pusat juga mengesahkan lambang-lambang partai (Ibrahim, 1981). Hal ini berarti kampanye mulai berjalan secara lebih luas dengan pengenalan lambang partai sebagai tanda dalam pemilu. Partai-partai mulai menyusun strategi dalam pemenangan pemilu.

Ditinjau dari aspek dukungannya, selama revolusi partai ini berkembang luas berlandaskan dukungan terutama dari elit administratif dan dari abangan kaum tani di Jawa. PNI memiliki pandangan utama yakni Marhaen atau "nasionalisme proletar" (Cribb \& Kahin, 2004). Basis utamanya ialah di dalam birokrasi dan kalangan pegawai kantor. Hal tersebut merupakan hal yang menguntungkan karena basis yang berasal dari kalangan pegawai atau priyayi akan sangat memberi pengaruh terhadap masyarakat pedesaan yang masih 
sangat menjunjung tinggi patron di kalangan masyarakat. Strategi yang menjadi inti dari gerakan politik PNI adalah penekanannya pada pemikiran Soekarno yang sangat populis, yakni marhaenisme. Dengan marhaenisme, partai ini memiliki daya tarik yang sangat besar bagi masyarakat muslim abangan karena partai ini dianggap merupakan imbangan utama terhadap keinginankeinginan politik Islam. Demikian pula, PNI mendapat banyak dukungan di daerah-daerah Kristen di luar Jawa dan di Bali yang menganut agama Hindu, di mana juga terdapat perasaan-perasaan anti-Islam (Feith, 2007; Ricklefs, 2007; Vickers, 2005).

Untuk mendekati kalangan abangan, PNI melakukan pendekatan pada aspek ekonomi sebagai salah satu strategi. Wacana yang disajikan PNI dalam mendekati kaum buruh adalah dengan mengkampanyekan wacana pemerintah Marhaenis. PNI mengusahakan terwujudnya pemerintah Marhaenis, yakni pemerintah yang ideologi dan usahanya selalu sesuai dengan kepentingan rakyat terbanyak yang miskin dan oleh karena itu dapat menjadi jaminan bahagia untuk rakyat seluruhnya. Aparatur masyarakat dan negara disusun untuk kepentingan Marhaen (Feith \& Castles, 1988). Untuk mencapai semua tujuan itu, jumlah anggota terbesar dari tiaptiap badan perwakilan rakyat harus terdiri dari kaum Marhaenis, yaitu pembela Marhaen dan prajurit yang berjuang untuk mewujudkan masyarakat Marhaenis. Dan untuk ini gerakan Marhaenis harus berjuang agar selalu menang dalam pemilu.

Di lambang PNI juga tertulis tulisan "Front Marhaenis" yang merupakan konsep yang diadopsi oleh Soekarno untuk melihat bagaimana realitas sejumlah besar dari masyarakat Indonesia, terutama petani mandiri yang walaupun sangat miskin dan ditekan oleh kapitalisme kolonial tetap pemilik yang mandiri dan tidak termasuk orang yang proletar (Cribb \& Kahin, 2004). Gambar banteng juga menjadi salah satu alat yang digunakan untuk menjaring suara pemilih. Dakam kampanye PNI, lambang banteng oleh para juru kampanyenya disebutkan sebagai lambang nasionalisme. Lambang ini memiliki makna walaupun sabar dan pelan, tetapi memiliki potensi yang besar untuk digerakkan (Feith, 1999; Suwirta, 2001).

Marhaenisme yang melatarbelakangi semangat PNI dalam berkampanye juga tampak dari berbagai iklan yang ditayangkan. Disebutkan bahwa "menusuk kepala banteng dalam segi tiga, berarti menuju masyarakat sama rata sama bahagia" (Feith, 1999). Selain itu dijelaskan pula dalam kampanyenya bahwa PNI adalah partai yang anti terhadap kolonialisme dan imperialisme, anti penjajahan, menggalakkan negara persatuan anti terhadap kemiskinan dan menyusun program ekonomi yang tegas. Dalam iklan kampanyenya dituliskan bahwa "menusuk kepala banteng dalam segi tiga berarti memilih front marhaenis yang anti kapitalisme dan imperialisme". Berdasarkan jargon tentang marhaenisme yang dikampanyekan dalam berbagai programnya, ada beberapa wacana lain yang juga dikampanyekan oleh PNI.

Selain mengangkat tentang marhaenisme, PNI juga mengampanyekan bahwa PNI memiliki kedekatan secara kultural dengan Soekarno sebagai pencetus paham marhaenisme. Strategi yang digunakan oleh PNI yaitu dengan mengedepankan aspek "Soekarno" dalam berbagai kegiatan kampanyenya. Hal ini menyebabkan masyarakat pedesaan yang begitu mengidolakan Soekarno tertarik untuk memilih PNI. Soekarno menjadi daya tarik bagi pemilih dari kalangan masyarakat karena mereka percaya bahwa Soekarno sebagai sosok ratu adil. Propaganda tersebut dilakukan dengan menerbitkan tulisan "Bung Karno Sudah Pasti Tusuk Tanda Gambar PNI”. Wacana tentang Bung Karno sebagai kader dari PNI merupakan sebuah wacana yang sangat penting dan efektif untuk menjaring suara dari kalangan masyarakat bawah yang sebagian dari mereka adalah masyarakat kawasan pedalaman dan cenderung lebih bersifat konformis dan agraris daripada masyarakat pesisir yang dinamis. Hal ini yang dimungkinkan menjadi faktor penentu kemenangan PNI yang sangat signifikan pada pemilu 1955 (Maulida, 2020).

Terkait dengan upaya melemahkan partai yang lain, PNI juga melakukan strategi melemahkan partai lawan. PNI memiliki pertentangan dengan Masyumi dengan berupaya untuk menjatuhkan Masyumi dalam kampanye-kampanyenya. PNI berusaha mengaitkaitkan Masyumi dengan Darul Islam dan ingin mengubah Pancasila lebih sebagai slogan anti-Islam daripada falsafah pengayoman (Sonhaji \& Maulida, 2020). Pertarungan antara dua kekuatan terkuat ini makin memanas ketika terjadi perubahan dari kabinet Ali Sasatroamidjojo yang berasal dari kader PNI ke Burhanuddin Harahap dari Masyumi, di mana tidak satupun orang PNI dimasukkan dalam kabinet. Hal yang paling sering diangkat PNI dalam wacana-wacana untuk menyerang Masyumi adalah wacana tentang Masyumi akan mengubah ideologi Indonesia menjadi negara Islam.

\section{Dugaan Penyelewengan Program Ekonomi Benteng}

Penyusunan strategi dalam pemenangan pemilu juga dilakukan oleh PNI dalam situasi yang sangat menguntungkan. Hal ini terjadi karena sebelum pelaksanaan pemilu, yakni dari bulan Juli 1953 sampai Juli 1955 dapat dikatakan bahwa PNI adalah partai 
penguasa sebab pada masa itu kabinet dipegang oleh Ali Sastroamidjojo yang merupakan seorang kader PNI. Beberapa kedudukan yang strategis dalam kabinet dan pemerintahan juga dipegang oleh PNI, yaitu Menteri Luar Negeri (Mr. Sunario), Menteri Keuangan (Dr. Ong Eng Die), Menteri Perekonomian (Mr. Iskaq Tjokrohadisoerjo). Selain itu, hal lain yang menguntungkan adalah bahwa pada tanggal 4 November 1953, kabinet membentuk Panitia Pemilihan Indonesia (PPI) yang diketuai oleh S. Hadikusumo yang juga seorang kader PNI. Hal ini memberikan pengaruh terhadap kepercayaan dan image di kalangan masyarakat bahwa PNI adalah sosok yang mampu memimpin negara (Feith, 1999).

Pada masa kabinet Ali, PNI menduduki posisiposisi strategis sehingga memudahkan langkah PNI dalam mencari dana kampanye (H Feith, 1999). Hal ini terlihat dari didudukinya jabatan-jabatan strategis dalam bidang perekonomian yang memudahkan PNI mendapatkan akses terhadap sumber-sumber dana yang berasal dari kalangan pengusaha, terutama pengusaha pribumi dan keturunan Cina sehingga memudahkan PNI dalam menggalang dana untuk kegiatan kampanye. Hal ini diperkuat dengan kebijakan Ong Engg Die sebagai Menteri Keuangan yang ditunjuk oleh secara langsung oleh PNI untuk melayani kepentingan politik PNI-yaitu memenangkan pemilihan umum 1955 ketimbangan melayani kepentingan ekonomi nasional (Wie, 2010).

Iskaq Tjokrohadisoerjo juga pernah membuat kebijakan yang dianggap kontroversial ketika memberikan instruksi kepada seluruh yayasan yang berada di bawah wewenang Kementerian Perekonomian untuk memindahkan rekeningnya dari bank-bank pemerintah kepada bank-bank swasta nasional. Beberapa bank swasta nasional yang dimaksud adalah Bank Umum Nasional, Bank Surakarta, serta Bank Perniagaan. Indikasi subjektifitas kebijakan Iskaq Tjokrohadisoerjo sangat nampak karena hampir keseluruhan jajaran direksi Bank Umum Nasional merupakan anggota PNI (Yani, 1995). Iskaq Tjokrohadisoerjo akhirnya diseret ke pengadilan pada 1958 dengan beberapa barang bukti di antaranya kepemilikan devisa di luar negeri berupa uang, tiket pesawat terbang, kereta, serta mobil tanpa seizin LAAPN (Lembaga Alat-Alat Pembayaran Luar Negeri) (Mulyadi, 2021; Priambodo dkk., 2020).

\section{SIMPULAN}

Republik Indonesia mendapatkan pengakuan kedaulatan atas kekuasaannya di wilayah bekas Hindia Belanda pada 27 Desember 1949 dalam KMB (Konferensi Meja Bundar). Walaupun pengakuan kedaulatan Republik Indonesia disambut dengan gembira oleh rakyat, namun banyak kaum nasionalis yang merasa tidak senang dengan beratnya persyaratan yang dibebankan Belanda kepada Indonesia sebagai imbalan atas pengakuan kedaulatan tersebut. Salah satu syarat tersebut yaitu Indonesia juga harus mengambil alih hutang Pemerintah Hindia Belanda di Indonesia. Seluruh hutang tersebut mencapai USD 1,13 miliar dalam negeri dan hutang luar negeri. Dampak dari pengambil alihan hutang tersebut membuat negara Indonesia menjadi semakin miskin.

Syarat yang sangat merugikan tersebut mendorong pemerintah Republik Indonesia untuk segera melaksanakan pembangunan nasional yang lebih terencana dan intensif. Pembangunan nasional Indonesia di bidang ekonomi pertama yang ditujukan untuk mengubah struktur ekonomi kolonial menjadi ekonomi nasional yaitu Program Benteng. Program Benteng yang dilaksanakan pada tahun 1950 - 1957 lebih diarahkan pada kegiatan perdagangan terutama perdagangan impor. Alasan mengapa kegiatan perdagangan yang diutamakan yaitu dilatarbelakangi oleh besarnya pendapatan Indonesia melalui perdagangan. Program Benteng yang bertujuan untuk memperkuat masyarakat pribumi Indonesia agar mampu menjadi pengusaha yang tangguh dan bersaing dengan pengusaha etnis Tionghoa dan Belanda yang lebih dulu terbentuk di Indonesia.

Dalam penyelenggaraannya, program ini banyak mengalami penyelewengan. Penyelewengan terjadi baik pada pengusaha pribumi Indonesia yang tidak kompeten sehingga mereka hanya menjadi pemburu rente serta menjual atau menyewakan lisensi impor mereka kepada pengusaha etnis Tionghoa. Kerjasama diantara mereka seringkali disebut dengan "Ali-Baba”. Selain itu, penyelewengan tidak hanya dilakukan oleh pemilik lisensi saja melaikan juga para pejabat pemerintah. Penyelewengan yang dilakukan oleh pejabat pemerintah berupa nepotisme atas dasar kesamaan partai politik, korupsi dan suap menyuap antara para pemburu rente dengan pejabat pemerintah. Dugaan psenyelewengan terutama dilakukan oleh beberapa anggota PNI yang menjabat pada posisi strategis untuk kepentingan pendanaan partai pada pemilu 1955.

\section{REFERENSI}

Boediono. (2005). Managing the indonesian economy: some lessons from the past. Bulletin of Indonesian Economic Studies, 41(3), 309-324.

Cribb, R. B., \& Kahin, A. (2004). Historical dictionary of indonesia. Scarecrow Press. 
Dick, H. W., Houben, V. J. H., Lindblad, J. T., \& Wie, T.K. (Ed.). (2002). The Emergence of a national economy: an economic history of indonesia, 1800-2000. Allen \& Unwin [u.a.].

Drakeley, S. (2005). The history of indonesia. Greenwood Press.

Febrari, R. (2015). Politik pemberantasan korupsi. Jakarta: Yayasan Pustaka Obor Indonesia.

Feith, H. (1999). Pemilihan umum 1955 di indonesia. Jakarta: Kepustakaan Populer Gramedia.

Feith, H, \& Castles, L. (1988). Pemikiran politik indonesia 1945-1965. Jakarta: LP3ES.

Feith, Herbert. (2007). The Decline of constitutional democracy in indonesia (1st Equinox ed). Equinox Pub.

Glassburner, B. (1962). Economic policy-making in indonesia, 1950-1957. Economic Development and Cultural Change, 10(2), 113-133.

Gottschalk, L. (1969). Understanding history: a primer of historical method. Knopf.

Ibrahim, H. (1981). Pemilihan umum di indonesia. Bandung: Sinar Bakti.

Kantaprawira, R. (2004). Sistem politik indonesia: suatu model pengantar. Bandung: Sinar Baru Algesindo.

Komala, D. (2012). Pengaruh kebijakan ekonomi program benteng terhadap pembentukan pengusaha pribumi tahun 1950-1957. Skripsi Tidak Diterbitkan, Universitas Pendidikan Indonesia. (http://a-research.upi.edu/skripsiview. php?export=html\&no_skripsi=10935)

Krekhof, J. V. D. (2005). Dutch enterprise in independent indonesia: cooperation and confrontation, 19491958. The Newsletter, 36(1), 1-18.

Kuntowijoyo. (2005). Pengantar ilmu sejarah. Yogyakarta: Bentang Pustaka.

Lindblad, J. T. (2019). The economic decolonisation of indonesia: a bird's-eye view. Journal of Indonesian Social Sciences and Humanities, 4, 1-20. https://doi. org/10.14203/jissh.v4i0.71

Lindblad, T. J. (2010). The importance of indonesianisasi during the transition from the 1930s to the 1960s. Itinerario, 26(3-4), 51-71.

Maarif, S. A. (1996). Islam dan politik: teori belah bambu masa demokrasi terpimpin (1959-1965). Bandung: Gema Insani Press.

Matansi, P. (2017). Benteng yang gagal memperkuat pengusaha pribumi. Tirto.id. https://tirto.id/ benteng-yang-gagal-memperkuat-pengusahapribumi-cyye

Maulida, F. H. (2020). Sejarah pemilu yang dihilangkan: pemilihan umum dalam kemelut politik indonesia tahun 1950-an. Jakarta: Media Pressindo.
Mulyadi, M. (2021). Tindak pidana korupsi sebagai tindak pidana khusus dalam rancangan kitab undang-undang hukum pidana. Jurnal Hukum Pidana \& Kriminologi, 2(1), 96-112.

Oey, B. T. (1991). Sejarah kebijakan moneter indonesia jilid i (1945-1958). Jakarta: Lembaga Pengembangan Perbankan Indonesia.

Pham, V. T. (2019). The Indonesian liberal democracy, 1950-1957. Dalam P. V. Thuỷ, Beyond Political Skin (hlm. 119-157). Springer Singapore. https://doi. org/10.1007/978-981-13-3711-6_4

Poesponegoro, M. D., \& Notosusanto, N. (2010). Sejarah nasional indonesia vi. Jakarta: Balai Pustaka.

Priambodo, E. R., Falah, M., \& Silaban, Y. P. (2020). Mengapa korupsi sulit diberantas. Jurnal Ilmu Hukum Humaniora dan Politik, 1(1), 30-41.

Ricklefs, M. C. (2007). Sejarah indonesia modern. Jakarta: Serambi Ilmu.

Schaff, A. (1976). History and truth (1st ed). Pergamon Press.

Setiono, B. G. (2008). Tionghoa dalam pusaran politik. Jakarta: Transmedia.

Sonhaji, M., \& Maulida, F. H. (2020). Komunikasi politik dan kecenderungan pilihan partai kaum santri dan abangan pada pemilu 1955. Nyimak: Journal of Communication, 4(1), 109-124.

Sukainah. (2016). Kebijakan ekonomi benteng dan dampaknya di surabaya tahun 1950-1955. Avatara, 4(3), 1230-1241.

Suwirta. (2001). Perbandingan antara pemilu 1955 dengan pemilu 1999. Fakultas Pendidikan Ilmu Pengetahuan Sosial, Universitas Pendidikan Indonesia.

Thee, K. W. (2005). Pelaku berkisah: ekonomi indonesia 1950-an sampai 1990-an. Jakarta: Pustaka Sinar Harapan.

Tim Buku Tempo. (2010). Hatta: Jejak yang melampaui zaman. Jakarta: Kepustakaan Populer Gramedia.

Vickers, A. (2005). A history of modern indonesia. Cambridge University Press.

Widagdo, H. B. (1995). Pemilu, pelanggaran, asas luber. Jakarta: Pustaka Sinar Harapan.

Wie, T. K. (2010). The debate on economic policy in newly-independent indonesia between sjafruddin prawiranegara and sumitro djojohadikusumo. Itinerario, 34(1), 35-56.

Wijayanti, Y. (2015). Kebijakan pemerintah indonesia masa orde lama di bidang ekonomi terhadap bisnis orang cina. Artefak Jurnal, 3(2), 113-118.

Yani, A. (1995). Kebijaksanaan menteri perekonomian iskaq tjokrohadisurjo pada masa kabinet ali pertama. Skripsi Tidak Diterbitkan. Universitas Indonesia. 